\title{
Optimization of Ultrasound Extraction of Cactus Pear (Opuntia ficus indica) Seed Oil Based on Antioxidant Activity and Evaluation of Its Antimicrobial Activity
}

\author{
María de los Angeles Ortega-Ortega, Nelly del Socorro Cruz-Cansino, \\ Ernesto Alanís-García, Luis Delgado-Olivares, José Alberto Ariza-Ortega, \\ Esther Ramírez-Moreno, and José de Jesús Manríquez-Torres
}

Centro de Investigación Interdisciplinario, Área Académica de Nutrición, Instituto de Ciencias de la Salud, Universidad Autónoma del Estado de Hidalgo, Circuito Actopan-Tilcuautla S/N Ex Hacienda La Concepción, 42160 San Agustín Tlaxiaca, HGO, Mexico

Correspondence should be addressed to Nelly del Socorro Cruz-Cansino; ncruz@uaeh.edu.mx

Received 20 February 2017; Accepted 9 April 2017; Published 27 April 2017

Academic Editor: Andrea Lauková

Copyright (C) 2017 María de los Angeles Ortega-Ortega et al. This is an open access article distributed under the Creative Commons Attribution License, which permits unrestricted use, distribution, and reproduction in any medium, provided the original work is properly cited.

\begin{abstract}
The purpose of the present study was to determine the optimal ultrasound conditions (amplitude level and time) for the extraction of cactus pear seed oil with the highest antioxidant activity using a closed system. Seed oil was analyzed for yield, antioxidant activity by ABTS and DPPH, and antimicrobial activity. Conventional extraction methods were assessed for comparison. Amplitude level significantly affected antioxidant activity in linear terms ( $p<0.0001 \mathrm{DPPH}$ and $p<0.001$ ABTS, resp.) so, at lower amplitudes, the higher antioxidant activity was achieved. The optimum ultrasound extraction conditions were of $78 \%$ amplitude for 10 min and yielded antioxidant activity values of $66.25 \mathrm{mg} \mathrm{AAE} / 100 \mathrm{~g}$ and $289 \mu \mathrm{mol} \mathrm{TE} / 100 \mathrm{~g}$ for ABTS and DPPH, respectively. Compared with conventional extraction methods, ultrasound exhibited lower oil yield and antioxidant activity but had the potential to achieve comparable results if multiple ultrasound extractions are performed in the time needed by conventional methods. Seed oils showed similar antimicrobial activity despite the extraction method and were more effective against Escherichia coli. The results demonstrated that ultrasound can be an alternative extraction method of seed oils from fruits such as cactus pear.
\end{abstract}

\section{Introduction}

Cactus pear fruit (Opuntia ficus indica) is common in arid and semiarid regions around the world [1]. This fruit that is mainly consumed fresh in Mexico [2] is composed by pulp, peel, and seeds [3]. According to several studies cactus pear fruit has bioactive compounds $[4,5]$ with high antioxidant and antimicrobial activity $[6,7]$. Some of these compounds are found in the seeds [8], which comprise 3 to $15 \%$ of the cactus pear pulp [9] and are usually considered waste after pulp processing [7]. Seeds also have a high content of oil $(98.8 \mathrm{~g} / \mathrm{kg})$ [10] characterized by high levels of linoleic and oleic acids [7] and other components as phenols [11], all which may contribute to human health [12]. Currently, seed oils have been used as natural agents for food preservation [13], and many have exhibited antimicrobial and antioxidant activity; some of these oils are from pumpkin [14], apple [15], black cumin [16], and basil [17] among other seeds. Cactus pear seeds from Opuntia dillenii also have a high antioxidant activity derived from bioactive compounds such as polyphenols and polyunsaturated fatty acids [18]. Some polyunsaturated fatty acids have also been identified in seeds from Opuntia ficus indica $[19,20]$ implying that these seeds may also have high antioxidant activity.

Seed oil is usually extracted by means of conventional methods such as Soxhlet and maceration, using heat, agitation, or long extraction times [21]. Microwave, supercritical fluids, and ultrasonic assisted extraction are unconventional methods that exert a physical effect on the sample [22]. Ultrasound has been used to extract antioxidants from many food materials including seeds. Ultrasound and ultrasoundassisted extractions use sound waves to produce cavitation 
microbubbles that collapse violently in the sample and facilitate the release and extraction of several compounds [23-25]. Some researchers had evaluated ultrasound-assisted extraction, in an open system, using a sonicator probe directly on the liquid sample to obtain seed oil from flaxseed [26], Korean pine [27], and pomegranate [28]. The purpose of the present study was to optimize the extraction conditions of cactus pear seed oil using ultrasound in a closed system based on antioxidant activity and using response surface methodology. Yield extraction and antioxidant and antimicrobial activity were compared with conventional methods.

\section{Materials and Methods}

2.1. Sample. Green cactus pear (Opuntia ficus indica), Reyna variety, was provided by the Mexican Association CoMeNTuna (Consejo Mexicano del Nopal y la Tuna A.C. of Actopan, Hidalgo, México) in spring of 2012. The green cactus pear seeds were obtained after several washes with water that removed the pulp and residues. The seeds were leaved to dry at ambient temperature until they reached a moisture of $6.43 \%$. After the seeds were crushed using an industrial mill (Cyclotec 1093, Tecator, Höganäs, AB, Sweden), the powder was passed through a mesh sieve to obtain a particle size of approximate $0.5 \mathrm{~mm}$ and then stored in sealed plastic bags at room temperature and dark conditions.

2.2. Ultrasound Extraction. Ultrasound (VCX-1500, Sonic \& Materials, Inc. Newtown, CT, USA) at $1500 \mathrm{~W}$, with a constant frequency of $20 \mathrm{kHz}$ and a probe of $25 \mathrm{~mm}$, was used for the extraction of green cactus pear seeds oil. Extraction from milled and sieved seeds (20 g) was carried out at an amplitude and time ranges of 80 to $90 \%$ and 5 to $15 \mathrm{~min}$, respectively, and a fixed outlet temperature of $25^{\circ} \mathrm{C}$. A sample of $400 \mathrm{~mL}$ was introduced in a jacketed vessel with water at $4^{\circ} \mathrm{C}$ circulating through the secondary layer [29]. After extraction, the aqueous and solid phases were separated by filtration using a vacuum pump (DOA-P704-AA, GAST Manufacturing, Inc., Benton Harbor, MI, USA). Both phases, aqueous and solid (this last was dried) (Weston 74-1001-w, Weston Products, L.L.C. Strongsville, OH, USA), were mixed with hexane for $30 \mathrm{~min}$ and then separated from the solvent by filtration. The aqueous phase was centrifuged (Allegra 25R, Beckman Couler, CA, USA) at 10,000 rpm for $30 \mathrm{~min}$ at $4^{\circ} \mathrm{C}$ and was stored in plastic containers and kept frozen until analysis. The solid phase was stored in hermetically sealed bags in the dark. The solvent obtained from the two phases was evaporated (BÜCHI Labortechnik AG, Flawil, SG, Switzerland) at $40^{\circ} \mathrm{C}$ to obtain the oil.

2.3. Soxhlet Extraction. Soxhlet extraction was performed according to the AOAC [30]. Milled and sieved seeds (5 g), hexane $(120 \mathrm{~mL})$, and a universal fat extraction system (Büchi Labortechnik AG, Flawil, SG, Switzerland) were used.

2.4. Maceration Extraction. Milled and sieved seeds (10 g) were introduced in a previously defatted cotton bag and then immersed in $200 \mathrm{~mL}$ of hexane in a closed glass at a temperature of $\approx 25^{\circ} \mathrm{C}$. After the sample was stored in a dark place for $24 \mathrm{hrs}$, the oil was obtained after solvent evaporation using a rotary evaporator (BÜCHI Labortechnik AG, Flawil, SG, Switzerland) at $40^{\circ} \mathrm{C}$.

2.5. Yield. Oil yield was determined according to Chougui et al. [31], using the following equation:

$$
\operatorname{Oil}(\%)=\left(\frac{M_{1}-M_{0}}{M_{2}}\right) \times 100,
$$

where $M_{0}$ is the weight of the empty Eppendorf tube (g), $M_{1}$ is the weight of the Eppendorf tube after evaporation ( $g$ ), and $M_{2}$ is the weight of the milled seeds ( $\mathrm{g}$ ).

The oil was stored in $2 \mathrm{~mL}$ amber Eppendorf tubes at $-32^{\circ} \mathrm{C}$ until analysis.

\subsection{Determination of Antioxidant Activity}

2.6.1. ABTS Assay. Antiradical capacity by ABTS was measured according to Kuskoski et al. [32]. The radical cation 2,2' azino-bis(3-ethylbenzthiazoline-6-sulfonic acid) diammonium salt $\left(\mathrm{ABTS}^{\circ+}\right.$ ) was produced by reacting $7 \mathrm{mM}$ ABTS stock solution with $2.45 \mathrm{mM}$ potassium persulfate in the dark at room temperature for 16 hrs before being used. The ABTS $^{\circ+}$ solution was diluted with deionized water to an absorbance of $0.70 \pm 0.10$ at $754 \mathrm{~nm}$. An aliquot of $20 \mu \mathrm{L}$ of sample was added to $980 \mu \mathrm{L}$ of the diluted $\mathrm{ABTS}^{\bullet+}$ solution, and absorbance readings were taken after 7 min incubation at room temperature. The absorbance of the mixture was measured at $754 \mathrm{~nm}$ in the microplate reader (Power Wave XS UV-Biotek, software KC Junior, VT, USA), and antioxidant capacity was expressed as $\mathrm{mg}$ ascorbic acid equivalent per $100 \mathrm{~g}$ of oil (mg AAE/100 g).

2.6.2. DPPH Assay. Antiradical activity was measured using 1,1-diphenyl-2-picrylhydrazyl $\left(\mathrm{DPPH}^{\circ}\right)$ radical as described by Morales and Jiménez-Pérez [33]. A methanol-acetate solution $(7.4 \mathrm{mg} / 100 \mathrm{~mL})$ of the stable $\mathrm{DPPH}^{\bullet}$ radical was prepared. A sample aliquot of $100 \mu \mathrm{L}$ was placed into vials and $500 \mu \mathrm{L}$ of $\mathrm{DPPH}^{\bullet}$ solution was added before the mixture was left to sit at room temperature for $1 \mathrm{hr}$. Finally, absorbance was measured at $520 \mathrm{~nm}$ in the microplate reader (Power Wave XS UV-Biotek, software KC Junior, Winooski, VT, USA), and antioxidant activity was expressed as $\mu \mathrm{mol}$ of Trolox equivalents per $100 \mathrm{~g}$ of oil $(\mu \mathrm{mol} \mathrm{TE} / 100 \mathrm{~g})$.

\subsection{Experimental Design}

2.7.1. Optimization. The optimization of the ultrasound extraction conditions was performed using the response surface methodology (RSM) with a central composite rotatable design for two independent extraction variables at five levels. The independent extraction variables (amplitude level: 80-90\%; time: 5-15 min) were determined based on preliminary experiments where higher antioxidant activity by ABTS and DPPH was observed. Design consisted in thirteen combinations with five central points replicates (Table 1). Experimental data were subjected to multiple nonlinear regression 
TABLE 1: Experimental design matrix.

\begin{tabular}{lccc}
\hline Number $^{\mathrm{a}}$ & \multirow{2}{*}{ Pattern } & $\begin{array}{c}\text { Amplitude level (\%) } \\
X_{i}\end{array}$ & Time (min) \\
\hline$(1)$ & 00 & 85 & $X_{j}$ \\
$(2)$ & +- & 90 & 10 \\
$(3)$ & ++ & 90 & 5 \\
$(4)$ & 00 & 85 & 15 \\
$(5)$ & $\mathrm{A} 0$ & 92 & 10 \\
$(6)$ & -- & 80 & 10 \\
$(7)$ & 00 & 85 & 5 \\
$(8)$ & $\mathrm{a} 0$ & 78 & 10 \\
$(9)$ & $0 \mathrm{~A}$ & 85 & 10 \\
$(10)$ & -+ & 80 & 17 \\
$(11)$ & 00 & 85 & 15 \\
$(12)$ & 00 & 85 & 10 \\
$(13)$ & $0 \mathrm{a}$ & 85 & 10 \\
\hline
\end{tabular}

${ }^{\mathrm{a}}$ Nonrandomized.

analysis (JMP 7.0.2, SAS Institute Inc., Cary, NC, USA) fitted to a second-order polynomial model:

$$
Y=\beta_{0}+\sum_{i=1}^{2} \beta_{i} X_{i}+\sum_{i=1}^{2} \beta_{i i} X_{i}^{2}+\sum_{i} \sum_{j=i+1} \beta_{i j} X_{i} X_{j},
$$

where $Y$ is the predicted response, $\beta_{0}$ is the constant coefficient, $\beta_{i}$ is the lineal coefficient, $\beta_{i i}$ is the quadratic coefficient, and $\beta_{i j}$ is the interaction coefficients. In this model, $X_{i}$ and $X_{j}$ are the independent extraction variables, amplitude level (\%), and time (min), respectively.

The adequacy of the mathematical model was determined using the coefficient $R^{2}$. The significance of the model regression coefficients was evaluated using an analysis of variance. Three-dimensional curves from the response surface plots were obtained to interpret the effects of the interaction between independent variables on the response variables. Contour plots were generated to represent the extrapolation and interpret the optimization of the extraction variables, using the Sigma Plot 12.3 graphing software (SYTAT software Inc., Richmond, CA, USA).

2.7.2. Treatment Comparison. Comparison between extraction methods (ultrasound-optimized Soxhlet and maceration) was carried out by a one-way analysis of variance (ANOVA). All determinations were performed in triplicate and significant differences between means were determined by Duncan test $(p \leq 0.05)$ using the SPSS program (15.0, SPSS Inc., Chicago, IL, USA).

2.8. Scanning Electron Microscopy. Scanning electron microscopy (SEM) was used to examine the morphological alterations caused to the cactus pear seeds before and after the ultrasound extraction. Samples deposited on the silicon wafer were coated with a thin layer of gold (Denton Vacuum Desk V, Moorestown, NJ, USA) applying 20 millitorr and
$20 \mathrm{~mA}$ during $4 \mathrm{~min}$. Samples were observed in a scanning electronic microcopy (JEOL JSM-6300, Peabody, MA, USA) at 1,000 and 500 amplifications and micrographs were taken to establish the structural comparison between both samples.

2.9. Antimicrobial Activity. The green cactus pear seed oil was tested against one Gram-positive bacteria, Staphylococcus aureus (ATCC 1654), and two Gram-negative bacteria, Escherichia coli (ATCC 25922) and Pseudomonas aeruginosa (ATCC 27853). All microorganisms were obtained from the Mexican Microbial Culture Collection of CINVESTAV of the National Polytechnic Institute (Mexico). For each microorganism, bacterial suspensions were made in a soybeancasein digest medium to a concentration of approximately $10^{8} \mathrm{CFU} / \mathrm{mL}$.

To evaluate the antimicrobial activity and the minimum inhibitory concentration (MIC), the disk diffusion method was used. Each bacterial suspension $(100 \mu \mathrm{L}$ from the $10^{8} \mathrm{CFU} / \mathrm{mL}$ ) was spread on prepared agar plates (sterile Standard Methods Agar for bacteria). Filter sterile paper discs ( $6 \mathrm{~mm}$ in diameter) were impregnated with $66.67,50,33.33$, and $16.67 \mu \mathrm{L}$ of the undiluted oil and were placed on the inoculated plates. The negative control was hexane, while ampicillin $(10 \mu \mathrm{g})$ and streptomycin $(10 \mu \mathrm{g})$ were used as positive controls. The plates where incubated at $37^{\circ} \mathrm{C}$ (Arsa AR-130, Felisa, Jalisco, Mexico) for 24 hrs. The diameters of the inhibition zones were measured in millimeters and the results of MIC were expressed as $\mu \mathrm{g} / \mu \mathrm{L}$.

\section{Results and Discussion}

3.1. Extraction Yield. Table 2 shows the oil yields achieved by the ultrasound treatments. The extraction yield varied from 3.75 to $6 \%$ and the maximum yield was obtained at the highest amplitude level of $92 \%$. Oil yield strongly depended on amplitude level probably because at high amplitudes the cavitation effect increases [21] and induces physical changes on the structure of the seed such as disruption of the cell walls, reduction of the particle size, and increase of exposure area. These conditions may facilitate the penetration of the solvent and thus the extraction of oil $[26,28,34]$. The maximum yield was achieved after $10 \mathrm{~min}$ of treatment, and longer times (15 min) at high amplitudes $(90 \%)$ did not increase oil extraction (Table 2). Albeit time is an important variable, after yield reaches a peak, a longer treatment does not maximize extraction; the same was described by Zhang et al. [27] for Korean pine seed, who demonstrated that oil yield increased with time, but when it reached a maximum, yield equilibrated and then decreased gradually. This may be attributed to an initial complete fracture of the cell walls during the first minutes of the cavitation effect $[26,28,34]$.

\subsection{Antioxidant Activity of Green Cactus Pear Seed Oil} Extracted by Ultrasound. Due to the complexity of the oxidation processes, it is advisable to perform more than one method to obtain the antioxidant profile of a sample [35]. In order to determine the antioxidant activity of the green 
TABLE 2: Extraction yield and antioxidant activity of green cactus pear seed oil extracted by ultrasound under different conditions.

\begin{tabular}{|c|c|c|c|c|}
\hline \multicolumn{2}{|c|}{ Extraction conditions } & \multirow[b]{2}{*}{ Oil yield (\%) } & \multicolumn{2}{|c|}{ Antioxidant activity } \\
\hline Amplitude level (\%) & Time (min) & & $\begin{array}{c}\text { ABTS } \\
\text { mg AAE/100 g }\end{array}$ & $\begin{array}{c}\text { DPPH } \\
\mu \mathrm{mol} \mathrm{TE} / 100 \mathrm{~g}\end{array}$ \\
\hline 85 & 10 & $5.75 \pm 0.03$ & $66.15 \pm 4.07$ & $246.10 \pm 0.92$ \\
\hline 90 & 5 & $4.15 \pm 0.01$ & $55.98 \pm 3.13$ & $141.76 \pm 3.90$ \\
\hline 90 & 15 & $4.85 \pm 0.02$ & $59.93 \pm 4.45$ & $167.02 \pm 1.14$ \\
\hline 85 & 10 & $5.25 \pm 0.01$ & $68.12 \pm 6.59$ & $236.01 \pm 3.22$ \\
\hline 92 & 10 & $6.00 \pm 0.06$ & $55.84 \pm 2.36$ & $101.63 \pm 4.68$ \\
\hline 80 & 5 & $5.25 \pm 0.01$ & $66.07 \pm 2.17$ & $267.07 \pm 7.37$ \\
\hline 85 & 10 & $3.75 \pm 0.00$ & $68.37 \pm 3.92$ & $245.05 \pm 2.37$ \\
\hline 78 & 10 & $5.40 \pm 0.10$ & $65.99 \pm 5.01$ & $289.26 \pm 0.26$ \\
\hline 85 & 17 & $5.60 \pm 0.06$ & $65.78 \pm 0.37$ & $260.09 \pm 1.33$ \\
\hline 80 & 15 & $5.40 \pm 0.00$ & $66.91 \pm 3.20$ & $284.96 \pm 0.93$ \\
\hline 85 & 10 & $5.75 \pm 0.00$ & $67.73 \pm 0.40$ & $277.55 \pm 1.71$ \\
\hline 85 & 10 & $5.30 \pm 0.10$ & $67.44 \pm 3.89$ & $245.08 \pm 2.92$ \\
\hline 85 & 3 & $5.50 \pm 0.10$ & $67.63 \pm 0.00$ & $250.05 \pm 1.99$ \\
\hline
\end{tabular}

\pm : standard deviation.

TABLE 3: Antioxidant activity regression coefficients of the ultrasound extraction conditions.

\begin{tabular}{lcc}
\hline Coefficient & ABTS & DPPH \\
\hline$\beta_{0}$ & $67.562964^{\mathrm{a}}$ & $249.96199^{\mathrm{a}}$ \\
$\beta_{i}$ & $-3.927762^{\mathrm{b}}$ & $-63.57459^{\mathrm{a}}$ \\
$\beta_{j}$ & 0.2724311 & 7.1702572 \\
$\beta_{i j}$ & 0.77572 & 1.8421052 \\
$\beta_{i i}$ & $-3.719624^{\mathrm{b}}$ & $-29.77102^{\mathrm{b}}$ \\
$\beta_{j j}$ & -0.826106 & 0.0425804 \\
$R^{2}{ }_{\text {adj }}$ & 0.93 & 0.96 \\
\hline$\beta_{i}:$ amplitude level; $\beta_{j} \cdot$ time; significance levels: ${ }^{\mathrm{a}} p<0.0001 ;{ }^{\mathrm{b}} p<0.001$
\end{tabular}

cactus pear seed oil, two parameters were evaluated: antioxidant and scavenging capacity by ABTS and DPPH, respectively. The results and experimental design are described in Table 2. Antioxidant activity ranged from 55.84 to $68.37 \mathrm{mg}$ AAE $/ 100 \mathrm{~g}$ for ABTS and 101.63 to $289.26 \mu \mathrm{mol} \mathrm{TE} / 100 \mathrm{~g}$ for DPPH. A $R^{2}$ value closest to one or at least of 0.80 indicates a good fit of the model [36]. The $R^{2}$ values for ABTS and DPPH were 0.93 and 0.96 , respectively (Table 3 ), indicating that the averages obtained adjusted to the mathematical response surface model.

3.3. Effect of Ultrasound Extraction Conditions on the Antioxidant Activity of Cactus Pear Seed Oil. In this study, a second-order polynomial model for predicting the antioxidant activity of green cactus pear seed oil was obtained by multiple linear regression analysis of the experimental data. Table 3 shows the regression coefficients and significant probabilities of the linear, quadratic, and interaction effects of the ultrasound conditions on the seed oil antioxidant activity. Both ABTS and DPPH values were significantly affected by amplitude level in linear term $\left(\beta_{i}\right)$ at $p<0.0001 \mathrm{DPPH}$ and $p<0.001 \mathrm{ABTS}$, respectively, as well as in its quadratic term $\left(\beta_{i i}\right)$ at $p<0.001 \mathrm{DPPH}$ and ABTS. The three-dimensional surface plots constructed to observe the effect of ultrasound processing (Figure 1) demonstrated that antioxidant activity was higher when the applied amplitude decreased.

\subsection{Optimization of the Ultrasound Extraction Conditions of} Cactus Pear Seed Oil. Optimal extraction conditions were selected from the overlapped contour plots in which the effect of amplitude level and time on the antioxidant activity of green cactus pear seed oil was considered.

Figure 2 shows the optimal zone where the highest antioxidant activity by ABTS and DPPH was achieved. The conditions corresponded to amplitude of $78 \%$ applied for $10 \mathrm{~min}$. In this zone the values for antioxidant activity were of $66.25 \mathrm{mg} \mathrm{AAE} / 100 \mathrm{~g}$ and $289 \mu \mathrm{mol} \mathrm{TE} / 100 \mathrm{~g}$ for ABTS and $\mathrm{DPPH}$, respectively.

\subsection{Comparison between Methods}

Extraction Yield and Antioxidant Activity. Figure 3 compares the oil yields obtained by the three extraction methods. The results revealed that the yield obtained using the optimized ultrasound extraction was significantly lower than the obtained with the Soxhlet and maceration procedures. The higher oil yield obtained by Soxhlet could be attributed to the constant and extended contact ( 4 to $6 \mathrm{hrs}$ ) of the sample with the solvent at high temperatures, in addition to the repeated washing cycles [37]. The ultrasound yield was closer to that of maceration method but this last one required longer time (24 hrs) as compared to $10 \mathrm{~min}$ ultrasound treatment.

The results of antioxidant activity by ABTS and DPPH are shown in Figure 4. Both parameters were significantly higher in the oil extracted by Soxhlet $(54.33 \pm 0.84 \mathrm{mg}$ AAE $/ 100 \mathrm{~g}$ and $266.60 \pm 1.97 \mu \mathrm{mol} \mathrm{TE} / 100 \mathrm{~g}$, resp.) compared to the other extraction methods. The ultrasound and maceration extractions exhibited similar antioxidant activity by ABTS, while DPPH was significantly higher for the ultrasound seed 


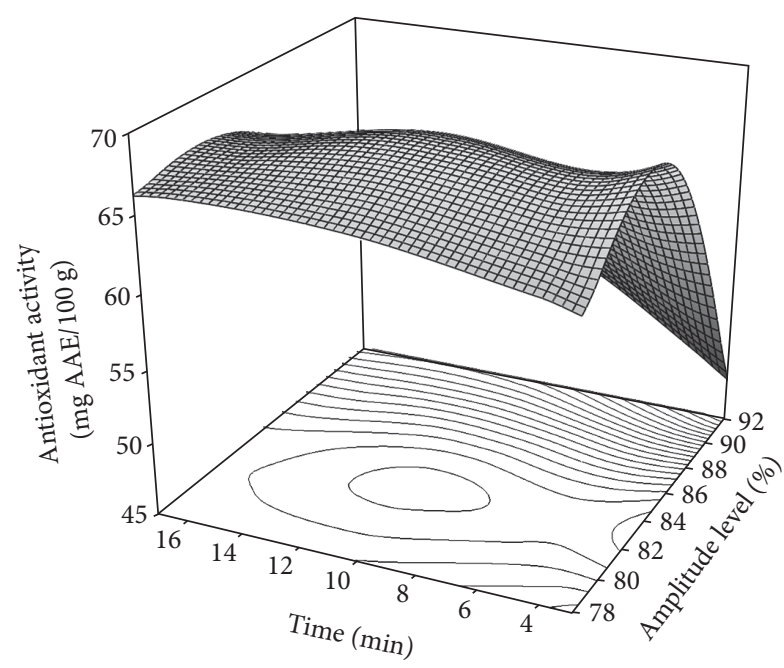

(a)

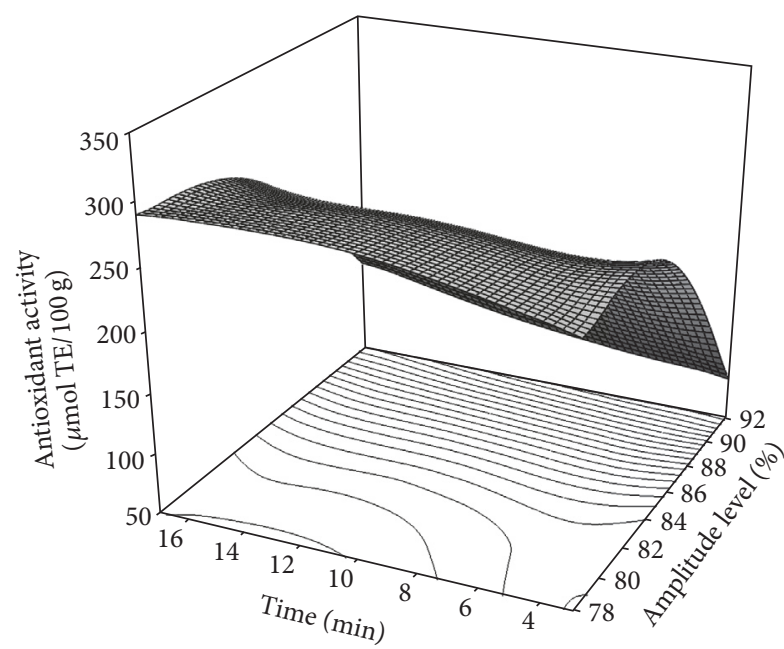

(b)

FIGURE 1: Effect of the ultrasound extraction on the antioxidant activity of green cactus pear seed oil. (a) ABTS; (b) DPPH.

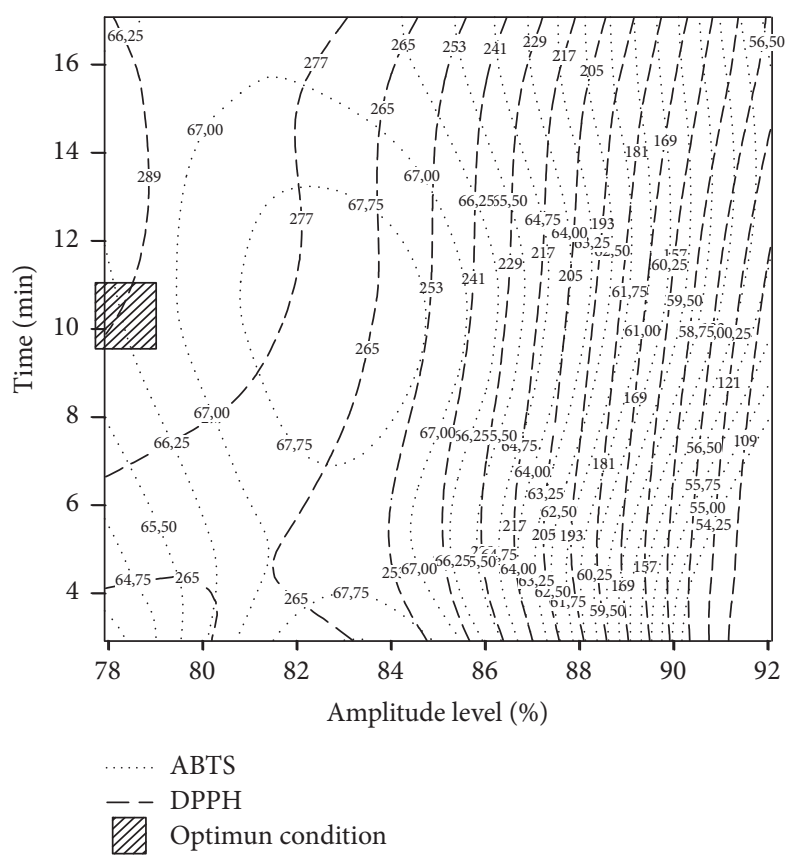

FIGURE 2: Optimal ultrasound extraction conditions of green cactus pear seed oil based on the highest antioxidant activity.

oil. Albeit the oil extracted by the Soxhlet method presented higher yield and antioxidant activity, the ultrasound-assisted extraction may be enhanced if multiple extractions are carried out in a time comparable to the required by the Soxhlet procedure (4-6 hrs).

3.6. Antimicrobial Activity. Escherichia coli and Staphylococcus aureus are distributed in nature (water, soil, and vegetation) and are also part of the human intestinal

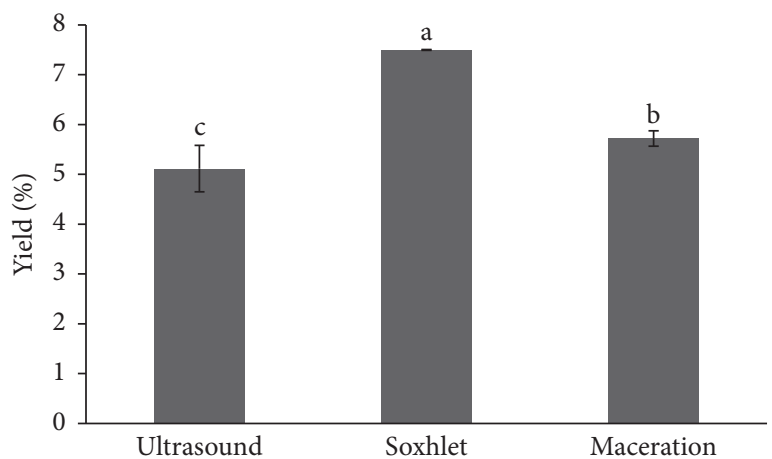

FIGURE 3: Cactus pear seed oil yield achieved by different extraction methods. ${ }^{\mathrm{a}, \mathrm{b}, \mathrm{c}}$ Different letters mean significant differences between methods $(p<0.05)$.

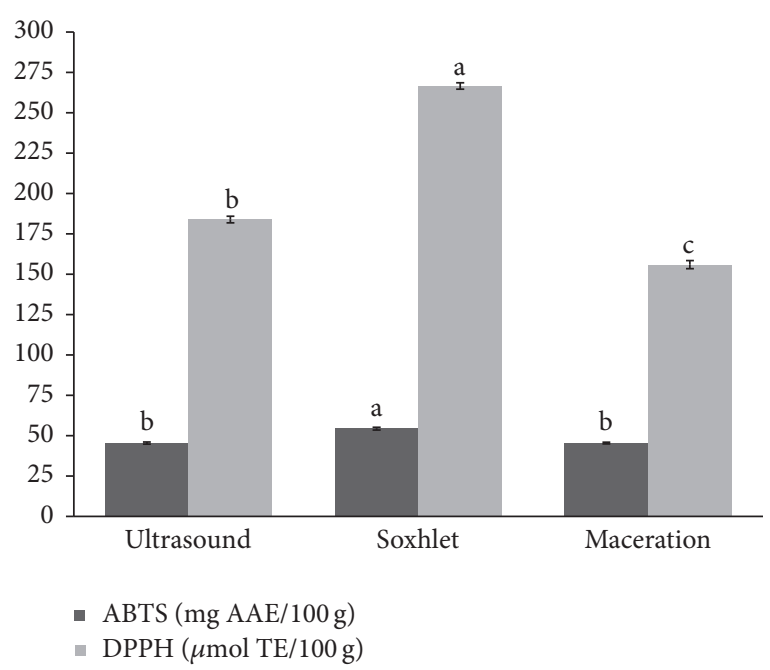

FIGURE 4: Antioxidant activity by ABTS and DPPH of cactus pear seed oil extracted by different methods. ${ }^{a, b, c}$ Different letters mean significant differences between methods $(p<0.05)$. 
TABLE 4: Antimicrobial activity of cactus pear seed oil extracted by different methods.

\begin{tabular}{|c|c|c|c|}
\hline & \multicolumn{3}{|c|}{ Diameter of inhibition zone (mm) } \\
\hline & Oil $^{*}$ & $(+)$ control & (-) control \\
\hline \multicolumn{4}{|c|}{ Staphylococcus aureus (Gram-positive) } \\
\hline Ultrasound & $9.17 \pm 0.29^{\mathrm{a}}$ & $18.89 \pm 1.54$ & ND \\
\hline Soxhlet & $9.50 \pm 0.87^{\mathrm{a}}$ & $18.78 \pm 1.64$ & ND \\
\hline Maceration & $9.78 \pm 0.69^{\mathrm{a}}$ & $18.11 \pm 1.17$ & ND \\
\hline \multicolumn{4}{|c|}{ Escherichia coli (Gram-negative) } \\
\hline Ultrasound & $7.78 \pm 0.19^{\mathrm{a}}$ & $15.56 \pm 2.12$ & ND \\
\hline Soxhlet & $7.56 \pm 0.19^{\mathrm{a}}$ & $15.33 \pm 2.65$ & ND \\
\hline Maceration & $7.56 \pm 0.38^{\mathrm{a}}$ & $14.00 \pm 2.33$ & ND \\
\hline \multicolumn{4}{|c|}{ Pseudomonas aeruginosa (Gram-negative) } \\
\hline Ultrasound & ND & $12.56 \pm 0.38$ & ND \\
\hline Soxhlet & ND & $12.22 \pm 0.38$ & ND \\
\hline Maceration & ND & $12.78 \pm 0.38$ & ND \\
\hline
\end{tabular}

microbiota [38]. Pseudomonas aeruginosa, besides being present in the intestinal microbiota [39], is a bacteria found in the soil, fertilizers, and water used for food production [40] and thus it can contaminate fresh or processed food, which is an indicator of inadequate sanitation or improper handling during food production [41]. Table 4 summarizes the antimicrobial activity of green cactus pear seed oil. Extraction method did not have a significant effect on the antimicrobial activity against Staphylococcus aureus and Escherichia coli, but the effect was lower than the positive controls. These results may be explained by the similar seed oil concentration and combined action of compounds on the structure of microbial cells $[42,43]$, despite the extraction method. Seed oil did not exhibit antimicrobial activity against Pseudomonas aeruginosa, probably due to the oil chemical composition, the type of microorganism, and the own characteristics of the bacteria [42-44]. The antimicrobial activity of oils is generally more effective against Gram-positive bacteria in comparison to Gram-negative bacteria, which are more resistant mainly because their outer membrane is less permeable [42, 43, 45, 46]. The results suggest that Pseudomonas aeruginosa was more resistant than Escherichia coli, probably due to the lipopolysaccharides present in the outer membrane that restrict the diffusion of compounds making it less permeable [45]. The resistance can also be caused by systems of exclusion pumps that eject antimicrobial compounds from the inside of the bacteria before they can cause damage $[39,44]$.

3.7. Effect of Ultrasound on the Physical Structure. Scanning electron micrographs of the green cactus pear seeds powder before and after the ultrasound treatment at magnifications factors of $1000 \mathrm{x}$ and $500 \mathrm{x}$ are shown in Figure 5. Before the ultrasound treatment and despite the previous milling process, in the control sample it was possible to identify intact structures of the seeds cell as well as some starch granules
(Figure 5(a)). After the ultrasound treatment, the cell structural damage and the variations in the shape and size of the particles were observed (Figure 5(b)). For instance, starch granules were not observed because sonication fragmented these particles while cavitation phenomenon disrupted the cell structures of the seeds $[47,48]$.

\section{Conclusions}

This study demonstrated that response surface methodology and a second-order polynomial model were effective tools to determine the optimum processing conditions of ultrasoundassisted extraction based on the maximum values of antioxidant activity. The results demonstrated that cactus pear seed oil has good antioxidant and antimicrobial properties. Ultrasound-assisted extraction was comparable to maceration but a single ultrasound process yielded less oil and lower antioxidant activity than solvent extraction (Soxhlet). Ultrasound can be considered an alternative technology for the extraction of seed oil but further research is required to determine the uses of the seed oil and the technology within the food industry and the potential of several ultrasound cycles at the optimized conditions.

\section{Conflicts of Interest}

The authors declare that there are no conflicts of interest.

\section{Acknowledgments}

This work was financially supported by Programa Integral de Fortalecimiento Institucional (PIFI 2014-2015). The authors acknowledge Mexican Association CoMeNTuna (Hidalgo, Mexico) for providing the plant materials. María de los Angeles Ortega-Ortega participated in this research and she 

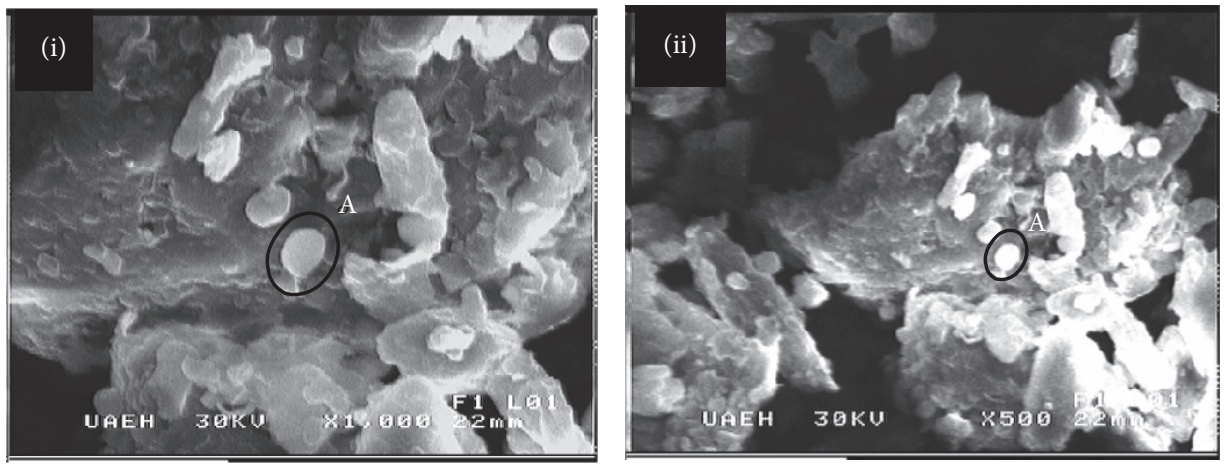

(a)
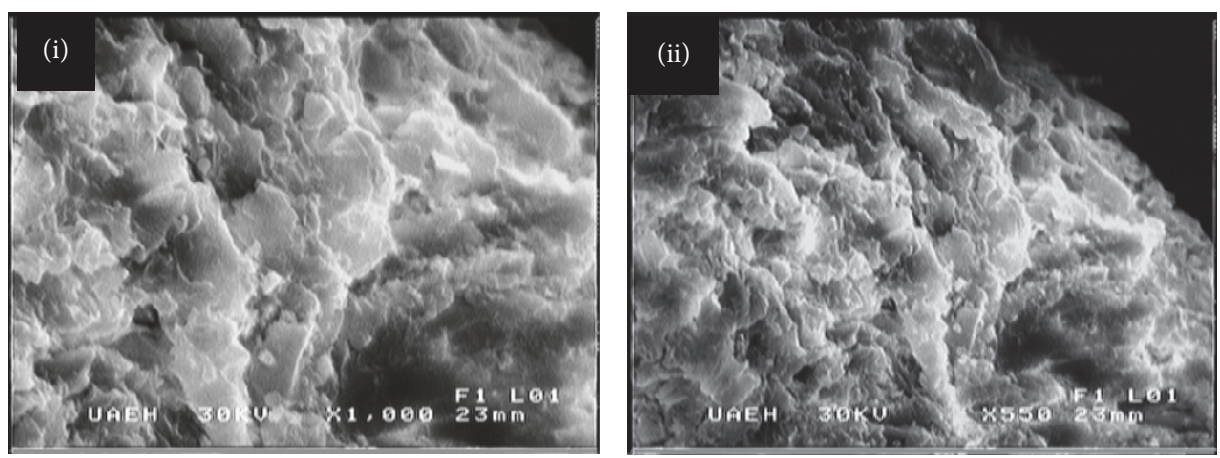

(b)

FIGURE 5: Scanning electron micrographs of green cactus pear seed powder before (a) and after (b) ultrasound treatment (i) 1,000x, (ii) 500x. A. The black circle shows a starch granule.

received her Bachelor's degree in nutrition, in the Universidad Autónoma del Estado de Hidalgo, México (Act no. 1287/ 2016).

\section{References}

[1] L. Lozano, "Ecofisiología de la tuna (Opuntia ficus-indica (L.) Mill.)," Horticultura Argentina, vol. 30, no. 72, pp. 37-52, 2011.

[2] L. Medina-Torres, J. A. Gallegos-Infante, R. F. Gonzalez-Laredo, and N. E. Rocha-Guzman, "Drying kinetics of nopal (Opuntia ficus-indica) using three different methods and their effect on their mechanical properties," LWT-Food Science and Technology, vol. 41, no. 7, pp. 1183-1188, 2008.

[3] J. A. Reyes-Agüero, J. R. Aguirre-Rivera, and H. M. Hernández, "Systematic notes and a detailed description of Opuntia ficus indica (L.) Mill. (Cactaceae)," Agrociencia, vol. 39, no. 4, pp. 395408, 2005.

[4] H. I. Jun, M. N. Cha, E. I. Yang, D. G. Choi, and Y. S. Kim, "Physicochemical properties and antioxidant activity of Korean cactus (Opuntia humifusa) cladodes," Horticulture Environment and Biotechnology, vol. 54, no. 3, pp. 288-295, 2013.

[5] A. Rabhi, H. Falleh, F. Limam, R. Ksouri, C. Abdelly, and A. Raies, "Upshot of the ripening time on biological activities, phenol content and fatty acid composition of Tunisian Opuntia ficus-indica fruit," African Journal of Biotechnology, vol. 12, no. 40, pp. 5875-5885, 2013.

[6] M. Kaur, A. Kaur, and R. Sharma, "Pharmacological actions of Opuntia ficus indica: a review," Journal of Applied Pharmaceutical Science, vol. 2, no. 7, pp. 15-18, 2012.
[7] M. R. Bhatt and P. S. Nagar, "Evaluation of physicochemical property and fatty acid composition of Opuntia elatior seed oil," Journal of the Professional Association for Cactus Development, vol. 15, pp. 13-19, 2013.

[8] M. Ennouri, H. Fetoui, E. Bourret, N. Zeghal, F. Guermazi, and H. Attia, "Evaluation of some biological parameters of Opuntia ficus indica. 2. Influence of seed supplemented diet on rats," Bioresource Technology, vol. 97, no. 16, pp. 2136-2140, 2006.

[9] SAGARPA. Secretaría de Agricultura, Ganadería, Desarrollo Rural, Pesca y Alimentación, Pliegos de condiciones para el uso de la marca oficial México calidad suprema en tuna, 2005, http://www.mexicocalidadsuprema.org/assets/galeria/PC_046_ 2005_Tuna.pdf.

[10] M. F. Ramadan and J.-T. Mörsel, "Oil cactus pear (Opuntia ficusindica L.)," Food Chemistry, vol. 82, no. 3, pp. 339-345, 2003.

[11] K. El-Mostafa, Y. Kharrassi, A. Badreddine et al., "Nopal Cactus (Opuntia ficus-indica) as a source of bioactive compounds for nutrition, health and disease," Molecules, vol. 19, no. 9, pp. 14879-14901, 2014.

[12] Z. Ghazi, M. Ramdai, M. L. Fauconnier, B. El Mahi, and R. Cheikh, "Fatty acids, sterols and Vitamin E composition of seed oil of Opuntia ficus indica and Opuntia dilenii from Morocco," Journal of Materials and Environmental Science, vol. 4, no. 6, pp. 967-972, 2013.

[13] B. Ozcan, M. Esen, M. K. Sangun, A. Coleri, and M. Caliskan, "Effective antibacterial and antioxidant properties of methanolic extrac of Laururs nobillis seed oil," Journal of Environmental Biology, vol. 31, no. 5, pp. 637-641, 2010. 
[14] A. Nawirska-Olszańska, A. Kita, A. Biesiada, A. SokólŁętowska, and A. Z. Kucharska, "Characteristics of antioxidant activity and composition of pumpkin seed oils in 12 cultivars," Food Chemistry, vol. 139, no. 1-4, pp. 155-161, 2013.

[15] V. Cervantes-Cardoza, N. E. Rocha-Guzmán, J. A. GallegoInfante, M. Rosales-Castro, L. Medina-Torres, and R. F. González-Laredo, "Actividad antioxidante de extractos de semilla de tres variedades de manzana (Malus domestica Borkh -Rosaceae-)," Boletín Latinoamericano y del Caribe de Plantas Medicinales y Aromáticas, vol. 9, no. 6, pp. 446-456, 2010.

[16] M. K. M. Nair, P. Vasudevan, and K. Venkitanarayanan, "Antibacterial effect of black seed oil on Listeria monocytogenes," Food Control, vol. 16, no. 5, pp. 395-398, 2005.

[17] A. I. Hussain, F. Anwar, S. T. H. Sherazi, and R. Przybylski, "Chemical composition, antioxidant and antimicrobial activities of basil (Ocimum basilicum) essential oils depends on seasonal variations," Food Chemistry, vol. 108, no. 3, pp. 986-995, 2008.

[18] W. Liu, Y. J. Fu, Y. G. Zu et al., "Supercritical carbon dioxide extraction of seed oil from Opuntia dillenii Haw. and its antioxidant activity," Food Chemistry, vol. 114, no. 1, pp. 334-339, 2009.

[19] M. T. Labuschagne and A. Hugo, "Oil content and fatty acid composition of cactus pear seed compared with cotton and grape seed," Journal of Food Biochemistry, vol. 34, no. 1, pp. 93$100,2010$.

[20] S. Zine, S. Gharby, and M. El Hadek, "Physicochemical characterization of Opuntia ficus-indica seed oil from Morocco," Biosciences Biotechnology Research Asia, vol. 10, no. 1, pp. 99105, 2013.

[21] R. Azuola and P. Vargas, "Extracción de sustancias asistida por ultrasonido (EUA)," Tecnología en Marcha, vol. 20, no. 4, pp. 3040, 2007.

[22] M. Gao and C. Z. Liu, "Comparison of techniques for the extraction of flavonoids from cultured cells of Saussurea medusa Maxim," World Journal of Microbiology and Biotechnology, vol. 21, no. 8-9, pp. 1461-1463, 2005.

[23] B. Karki, B. P. Lamsal, S. Jung et al., "Enhancing protein and sugar release from defatted soy flakes using ultrasound technology," Journal of Food Engineering, vol. 96, no. 2, pp. 270-278, 2010.

[24] F. Adam, M. Abert-Vian, G. Peltier, and F. Chemat, "'Solventfree' ultrasound-assisted extraction of lipids from fresh microalgae cells: a green, clean and scalable process," Bioresource Technology, vol. 114, pp. 457-465, 2012.

[25] T. Allaf, V. Tomao, K. Ruiz, and F. Chemat, "Instant controlled pressure drop technology and ultrasound assisted extraction for sequential extraction of essential oil and antioxidants," Ultrasonics Sonochemistry, vol. 20, no. 1, pp. 239-246, 2013.

[26] Z. S. Zhang, L. J. Wang, D. Li, S. S. Jiao, X. D. Chen, and Z. H. Mao, "Ultrasound-assisted extraction of oil from flaxseed," Separation and Purification Technology, vol. 62, no. 1, pp. 192198, 2008.

[27] T. Zhang, Z. Wang, and X. Chen, "Ultrasound-associated extraction of seed oil of Korean pine," Journal of Forest Research, vol. 16, no. 2, pp. 140-142, 2005.

[28] A. M. Goula, "Ultrasound-assisted extraction of pomegranate seed oil-kinetic modeling," Journal of Food Engineering, vol. 117, no. 4, pp. 492-498, 2013.

[29] Q. Y. Zafra-Rojas, N. S. Cruz-Cansino, A. Quintero-Lira et al., "Application of ultrasound in a closed system: optimum condition for antioxidants extraction of blackberry (Rubus fructicosus) residues," Molecules, vol. 21, no. 7, p. 950, 2016.

[30] AOAC, Official Methods of Analysis, AOAC International, Gaithersburg, Md, USA, 18th edition, 2005.

[31] N. Chougui, A. Tamendjari, W. Hamidj et al., "Oil composition and characterisation of phenolic compounds of Opuntia ficusindica seeds," Food Chemistry, vol. 139, no. 1-4, pp. 796-803, 2013.

[32] E. M. Kuskoski, A. G. Asuero, A. M. Troncoso, J. Mancini-Filho, and R. Fett, "Aplicación de diversos métodos químicos para determinar actividad antioxidante en pulpa de frutos," Ciência e Tecnologia de Alimentos, vol. 25, no. 4, pp. 726-732, 2005.

[33] F. J. Morales and S. Jiménez-Pérez, "Free radical scavenging capacity of Maillard reaction products as related to colour and fluorescence," Food Chemistry, vol. 72, no. 1, pp. 119-125, 2001.

[34] Y. Tian, Z. Xu, B. Zheng, and Y. Martin Lo, "Optimization of ultrasonic-assisted extraction of pomegranate (Punica granatum L.) seed oil," Ultrasonics Sonochemistry, vol. 20, no. 1, pp. 202-208, 2013.

[35] M. L. Agudo, “Técnicas para la determinación de compuestos antioxidantes en alimentos," 2010, http://www.anpebadajoz.es/ autodidacta/autodidacta_archivos/numero_9_archivos/1_a_ medina.pdf.

[36] S. K. Ho, C. P. Tan, Y. Y. Thoo, F. Abas, and C. W. Ho, "Ultrasound-assisted extraction of antioxidants in Misai Kucing (Orthosiphon stamineus)," Molecules, vol. 19, no. 8, pp. 1264012659, 2014.

[37] S. R. Kirk, R. Sawyer, and H. Egan, "Métodos químicos generales," in Composición y Análisis de Alimentos, pp. 25-29, Compañía editorial continental, Ciudad de México, México, 2002.

[38] S. Vázquez, S. O’Neill, and M. Legnani, "Importancia de los coliformes en los alimentos," 2013, http://www.montevideo.gub .uy/sites/default/files/importancia_de_los_coliformes_en_los_ alimentos.pdf.

[39] C. A. Gómez-Álvarez, A. L. Leal-Castro, M. J. Pérez de Gonzalez, and M. L. Navarrete-Jiménez, "Mecanismos de resistencia en Pseudomonas aeruginosa: entendiendo a un peligroso enemigo," Revista de la Facultad de Medicina de la Universidad Nacional de Colombia, vol. 53, no. 1, pp. 27-34, 2005.

[40] S. D. Kominos, C. E. Copeland, B. Grosiak, and B. Postic, "Introduction of Pseudomonas aeruginosa in to a hospital via vegetables," Applied Microbiology, vol. 24, no. 4, pp. 567-570, 1972.

[41] NOM, Norma Oficial Mexicana NOM-210-SSA1-2014, Productos y servicios, Métodos de prueba microbiológicos, Determinación de microorganismos indicadores, Determinación de microorganismos patógenos, 2014, http://dof.gob.mx/ nota_detalle.php? codigo $=539868 \&$ fecha $=26 / 06 / 2015$.

[42] F. Reyes-Jurado, E. Palou, and A. López-Malo, "Métodos de evaluación de la actividad antimicrobiana y de determinación de los componentes químicas de los aceites esenciales," Temas Selectos de Ingeniería de Alimentos, vol. 8, pp. 68-78, 2014.

[43] D. Zekaria, "Los aceites esenciales una alternativa a los antimicrobianos," 2015, http://www.wpsa-aeca.es/aeca_imgs_docs/ wpsal182855355a.pdf.

[44] D. M. Livermore, "Multiple mechanisms of antimicrobial resistance in Pseudomonas aeruginosa: our worst nightmare?" Clinical Infectious Diseases, vol. 34, no. 5, pp. 634-640, 2002.

[45] M. Viuda-Martos, M. A. Mohamady, J. Fernández-López et al., "In vitro antioxidant and antibacterial activities of essentials oils obtained from Egyptian aromatic plants," Food Control, vol. 22, no. 11, pp. 1715-1722, 2011. 
[46] X. Feás, L. M. Estevinho, C. Salinero et al., "Triacylglyceride, antioxidant and antimicrobial features of virgin camellia oleifera, C. reticulata and C. sasanqua oils," Molecules, vol. 18, no. 4, pp. 4573-4587, 2013.

[47] R. G. Earnshaw, "Ultrasound: a new opportunity for food preservation," in Ultrasound in Food Processing, M. J. W. Povey and T. J. Mason, Eds., pp. 183-192, Editorial Black Academic and Professional, New York, NY, USA, 1998.

[48] M. Vinatoru, "An overview of the ultrasonically assisted extraction of bioactive principles from herbs," Ultrasonics Sonochemistry, vol. 8, no. 3, pp. 303-313, 2001. 

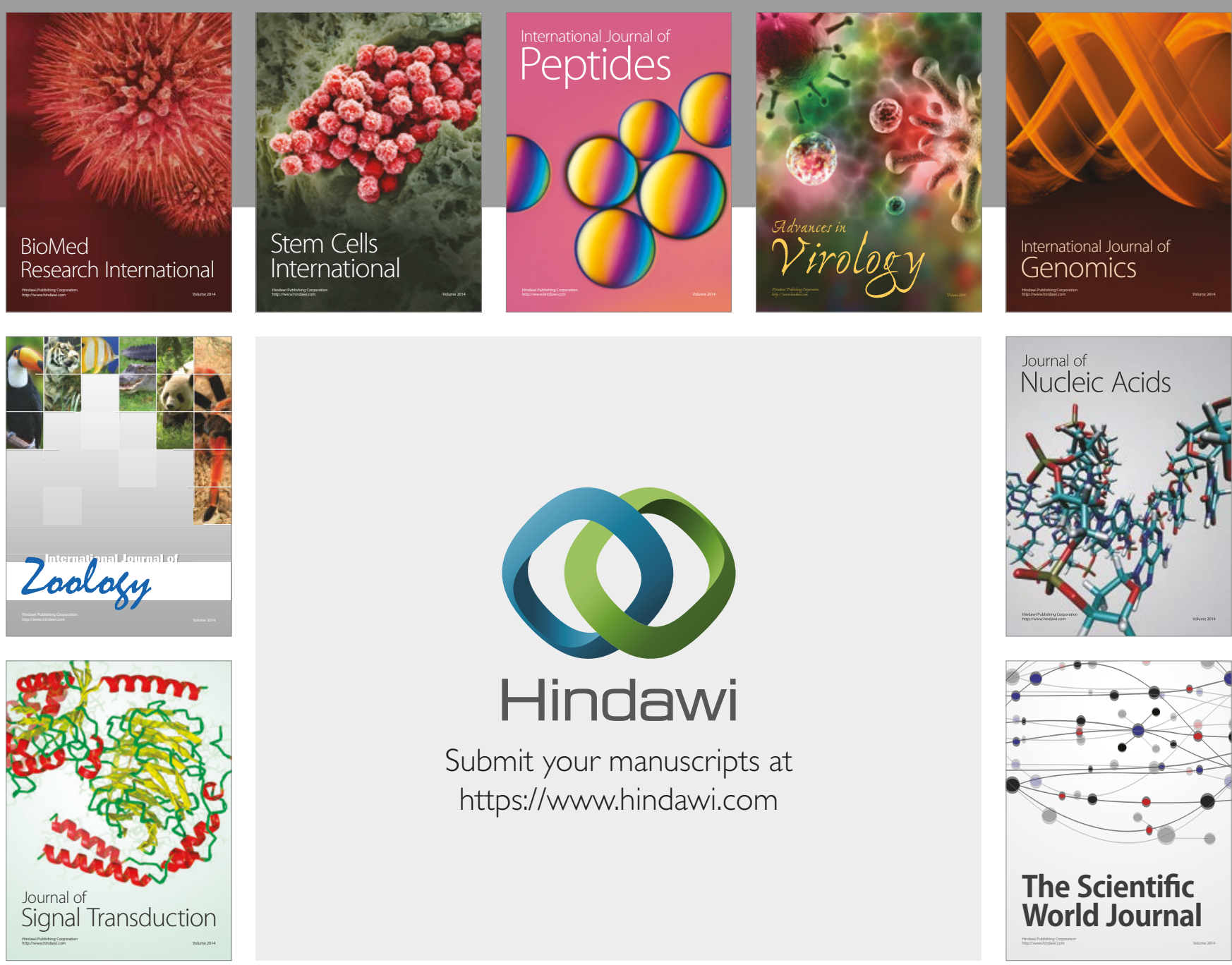

Submit your manuscripts at

https://www.hindawi.com
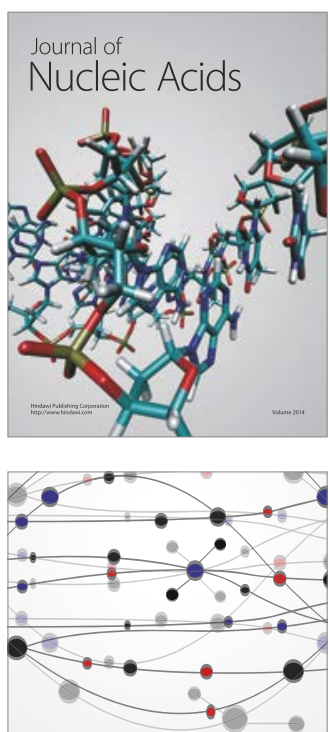

The Scientific World Journal

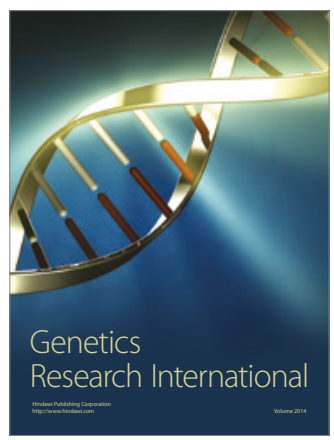

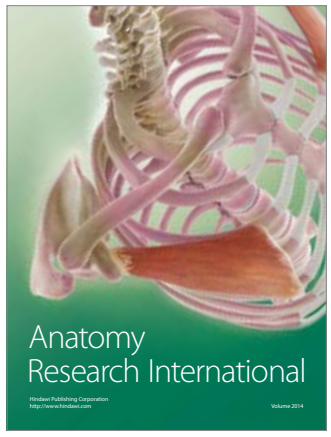

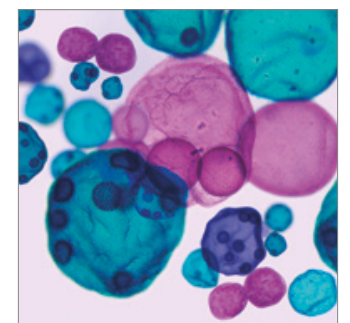

International Journal of Microbiology
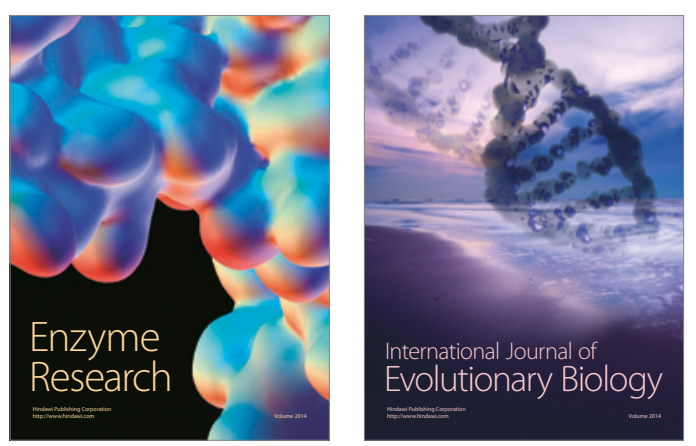
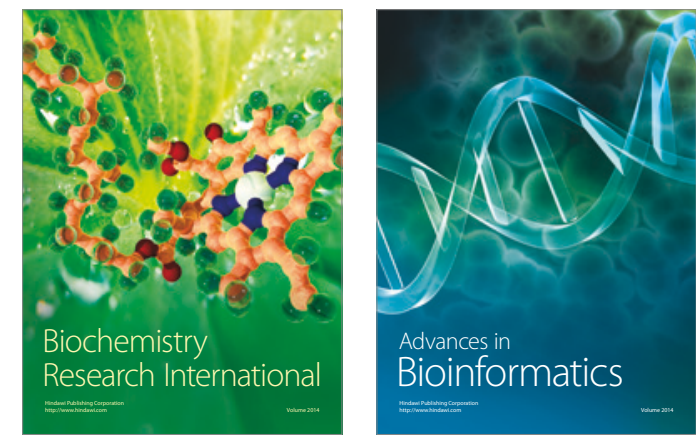

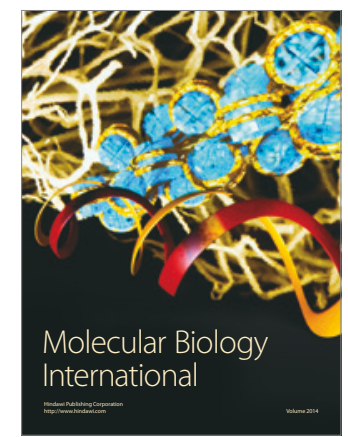

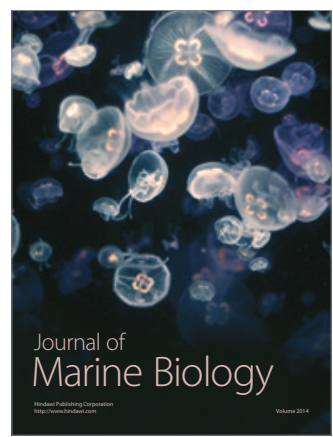

